\title{
Designing, Construction and Analysis of Speed Control System of the Fan with PV Feeding Source in an Air Solar Collector
}

\author{
Amir Hematian \\ Department of Agricultural Machinery, University of Tabriz, Iran \\ Tel: 98-91-8330-6978_E-mail: amir.hematian88@ms.tabrizu.ac.ir \\ Yahya Ajabshirchi \\ Department of Agricultural Machinery, University of Tabriz, Iran \\ Tel: 98-91-4406-8997Ｅ-mail: yajabshir@tabrizu.ac.ir \\ Hossein Behfar \\ Department of Agricultural Machinery, University of Tabriz, Iran \\ Tel: 98-91-4300-8753Ｅ-mail: behfar@tabrizu.ac.ir \\ Hessamoddin Ghahramani \\ Post operator of mixed cycle powerhouse of Kermanshah-Zagros \\ Tel: 98-91-8919-1121_E-mail: hessam_ghahramani_hec@yahoo.com
}

Received: August 15, 2011

doi:10.5539/max.v6n1p136
Accepted: November 17, $2011 \quad$ Published: January 1, 2012

URL: http://dx.doi.org/10.5539/max.v6n1p136

\begin{abstract}
Solar energy is one of the renewable energy sources which can be received more by designing more accurate systems. In this article a flat solar collector with the area of $2 \times 1 \mathrm{~m}^{2}$ and thickness of $0.5 \mathrm{~mm}$, made of steel iron in the form of venetian blinds (in order to increase exposure to air) has been used. The surface of absorber plate was black and for insulation of the body of the collector glass wool has been used with $5 \mathrm{~cm}$ thickness. One of the essential problems of air solar collectors is that the temperature of the outlet air temperature from the collector is variable during the day and their efficiency is low in the last hours of the day and also when the weather suddenly gets cloudy. In this study, to keep constant the outlet air temperature from the collector consistent in the desired limits, a control system is designed and constructed by applying photovoltaic cells, a microcontroller (AVR) and temperature sensors (LM35). Three temperature sensors were installed in the outlet of the collector. The experiment results showed that by automatic change of the fan's speed in the designed system, the outlet temperature of the collector was obtained in the desired ranges which is an outstanding advantage for various applications.
\end{abstract}

Keywords: Solar collectors, Photovoltaic cells, Control system, Temperature sensors

\section{Introduction}

Air collectors are generally used to heat or preheat the air. Design, material and construction methods for solar air collectors have been developed gradually. The efficiency of air collectors is low, because air has low heat capacity and low heat transfer coefficient. The most important advantage of air collectors is that they don't have freezing and pressure problem which in total reduces the cost of the production and have no heat convertor to get warm directly from the air (Parker, et al., 1993). To increase heat efficiency, the heat must be transferred to the absorbers efficiently; therefore, to improve heat transfer and air moving through the various directions, many designs have been done in the geometrical form of the absorber plate. Choundhury et al. (1988), in order to simply change the absorber plate, suggested a big striped plate. Garg and et al. (1991) suggested an absorber plate with fins joined to it. Henden and et al (2002) stated that the main hindrance in wide application of solar heating systems is their high cost in comparison with common heating systems. 
Zomorodian and Woods (2003) constructed and tested a sample model from collectors with stepped coating and pitted absorber plate. According to their reports the air which almost vertically is absorbed from the covering layer to the absorber plate, causes the covered plate to cool down and the convection losses are reduced considerably. Karim and Hawlader (2004) constructed and tested a sample model of collectors with flat plates and finned plates. The results showed that the collectors with flat plates have low efficiency in comparison with the collectors with finned plates and applying finned plates helped to increase the temperature up to 10 percent. Mokhtari and Samar (1999) carried out an experimental study on the solar collectors in natural and forced flow conditions. They demonstrated that in a natural convection, when the inlet air temperature is $25^{\circ} \mathrm{C}$ the temperature of the collector reaches to $75^{\circ} \mathrm{C}$ and in the forced convection, when the inlet air temperature is $27^{\circ} \mathrm{C}$, in outlet it reaches to $53^{\circ} \mathrm{C}$.

Nowadays the application of control systems in engineering and science has a pivotal role and is a factor to reach for optimum efficiency in dynamic systems, increase in output and also facilitation of manual repetitive tasks (Diyani, 2002). Fouler and Charters (1997) constructed an automatic control system of fan for solar tunnel collectors. This system has been designed to decrease the amount of consumption power needed for the fan through the change of its speed in accordance with the change in the conditions. By applying this method the performance time of the fan decreased 67 percent in comparison with the continuous performing state. Naybrunt (1985), by applying a controller, adjusted the temperature and humidity of the grains in a solar dryer efficiently. The results of the experiments showed that by applying control systems the temperature can be precisely adjusted. The purpose of this study is to create a mechanism in using solar energy for various applications. In this study, the control system designed with using of photovoltaic cells and without AC power. This system kept the outlet temperatures of collector in the determined ranges. Temperature stabilization in the outlet of collector decreases the energy losses. In this research the management of energy consumption is important in two aspects: the first is use of solar energy instead of fuel energy and the second is decreasing of heat losses in collectors.

\section{Materials and Methods}

\subsection{The Applied Solar Collector}

To carry out the performance tests an active collector was used with the size of $2 \times 1 \times 0.15 \mathrm{~m}$. The wall of the collector was from iron profile which was insulated by glass wool with the thickness of $5 \mathrm{~cm}$. The absorber plate was from steel with the thickness of $0.5 \mathrm{~mm}$ which was painted black. In order to decrease heat loss through the absorber plate it was insulated underneath by glass wool with $5 \mathrm{~cm}$ thickness. The cover of the collector was a transparent glass with $4 \mathrm{~mm}$ thickness. To increase the contact surface of the absorber plate with the hot air inside the collector some ducts were designed and mounted on the absorber plate as it is illustrated in Figure 1. To provide inlet air to the collector in a way that the outlet air is kept consistent in the desired ranges, a fan was used which could turn with different speeds. The desired outlet temperatures which were intended for programming the microcontroller included: 31 to 35,36 to 40,41 to 45,46 to 50 and 51 to $55^{\circ} \mathrm{C}$. Air flow simultaneously occurred through the channel 1 (under the absorber plate) and the channel 2 (over the absorber plate). A microcontroller was used to provide the various rotations of the fan. The required energy for operation the components of the controller circuit was provided through two solar panels with the size of $20 \times 15 \mathrm{~cm}^{2}$ and they each had a $5 \mathrm{~W}$ power. Voltage, amperage and power the fan were $12 \mathrm{~V}, 0.48 \mathrm{~A}$ and $5.76 \mathrm{~W}$ respectively. The different components of the system under test are illustrated in Figure 2.

\subsection{Designing a Control System and Carrying Out the Tests}

To measure the temperature in the outlet of the collector three temperature sensors were used which were installed with a specific distance from each other and a temperature sensor was used to measure the inlet temperature in the entrance of the collector. The control circuit was located on a board and a small monitor was used to show the inlet and outlet temperatures. The collector was positioned in the 29.5 degrees latitude in north-to- south direction in an open area of the building No.2 faculty of agriculture of Tabriz University. The tests with the above mentioned system was carried out for seven days, from 18 to 24 June 2011 and 12 hours per day (from 8 a.m. to 8 p.m. local time). Throughout all hours of testing the amount of solar radiation was measured by TES 1333 solar meter, the speed of the outlet air from the collector was measured by a speed meter type of hot wire 20004 AHYK with the precision of $0.1 \mathrm{~m} / \mathrm{s}$ and speed of the fan was measured by infrared eyelet. Figure 3, shows schematic of the control system and table 1 shows the average of the data in seven days of testing.

\subsection{Calculation of the Collector Temperature Efficiency}

Due to better insulation and ability of more absorption of solar radiation, collectors show better performance. These two parameters cause increscent of collector's performance. The heat loss from the top of the solar 
collector is high and from beneath and sides of it are the least (Bagheri, et al., 2010). Figure 4, shows schematic solar radiation and different types of heat loss from a flat collector. The output of a solar collector is defined as follows (Aydin, 2005; Kurtbash \& Durmush, 2004):

$$
\begin{gathered}
\eta=\frac{Q_{\text {useful }}}{Q} \\
Q_{\text {useful }}=\dot{m} C_{p}\left(T_{\text {out }}-T_{\text {in }}\right) \\
Q=I_{\beta} \cdot A_{c}
\end{gathered}
$$

In which $Q_{u s e f u l}$ is the useful collected energy by the collector (W) and $Q$ is the solar energy arrived on the surface of the collector (W), $m$ is the rate of air mass flow $(\mathrm{kg} / \mathrm{s}), C_{p}$ is the specific heat capacity of the air at constant pressure $\left(\mathrm{J} / \mathrm{kg} .{ }^{\circ} \mathrm{K}\right), T_{\text {out }}-T_{\text {in }}$ is the difference between the inlet and outlet temperature $\left({ }^{\circ} \mathrm{K}\right), I_{\beta}$ is the solar radiating on every square meter of the collector $\left(\mathrm{W} / \mathrm{m}^{2}\right)$ which is measurable by a solar meter and Ac is the surface of the solar collector $\left(\mathrm{m}^{2}\right)$.

\section{Result and Discussion}

\subsection{Evaluation of the Amount of Radiation}

The average of solar radiation measured by solar meter and solar radiation received by collector are shown in Figure 5. As it can seen in this figure, the amount of radiation in the early hours of the day and the finishing hours of the day has the lowest value. But as it seen in the figure, the amount of radiation in the early hours is more than the finishing hours of the day. The maximum radiation occurs between 12 to 13 o'clock, because at interval the rays of the sun shine on the collector are vertically and therefore the amount of reflected rays is minimum.

\subsection{Temperature Variations, Fan Speed and the Velocity of the Outlet Air}

Figure 6, shows the average of inlet and outlet temperatures of the collector during the testing days. According to this figure, the received solar energy by the collector causes to increase the temperature of the absorber plate and this increases the temperature of the passing air. As it is illustrated in Figures 5 and 6, the maximum received radiation energy by the collector occurs between 12 to 13 o'clock, but the maximum temperature increase of the collector occurs between 13 to 14 o'clock. This phenomenon can be explained in this way that due to the thickness of absorber plate, it needs more time to increase in temperature. Soheili Mehdi-zadeh (2009), Nadi (2006) and Bagheri et al. (2010) have come to the same conclusion in their studies.

The changes of the outlet air temperature from the collector in comparison with the changes of the inlet air temperature are insignificant and its curve is less steep. This is because of the speed control of the fan and to some extent due to the saving of the energy in the absorber plate. At low temperature the rotation and speed of the fan slows down and air moves over the absorber plate with a lower speed and this increases the temperature. As the outlet temperature increases, considering the set temperatures for the microcontroller, the rotation of the fan increases and the speed of the air movement in the collector increases accordingly and this causes the outlet air to be consistent in the desired ranges. Soheili Mehdi-zadeh et al. (2010) have reached to the same conclusion in their studies.

Figures 7 and 8 show the average changes of the fan's rotation and the speed of the outlet air from the collector. Speed and rotation have a direct relation to each other, thus; the trend of the curves is similar to each other. According to the curves, the maximum average of the fan rotation and the speed of the outlet air occur since 13 until 14 o'clock, and considering this fact we can figure out the relation between these parameters and the outlet air temperature, because as it is explained before the outlet temperature is maximum from 13 to 14 o'clock.

\subsection{Determining Temperature Output of the Solar Collector}

Table 2 , shows the rate of air mass flow $(\dot{m})$, the specific heat capacity of the air at constant pressure $\left(C_{p}\right)$, the temperature difference between the inlet air and outlet one $(\Delta \mathrm{T})$, the solar radiation per square meter $\left(I_{\beta}\right)$, the value of useful energy of the collector ( $Q_{u s e f u l}$ ) which is obtained from equation 2, the value of total energy of the collector ( $Q$ ) which is obtained from equation 3 and collector efficiency which is obtained from equation 1 , all during the testing hours.

As it can be seen in the Table 2 and the Figure 9, in the tests carried out in different days of testing, the average efficiency of the solar collector has an ascending tendency, and only in some intervals, i.e., 12-13, 14-15 and 19-20 there is a descending streak in it which is due to sudden change of weather conditions and cloudiness 
which affected the average inlet and outlet temperatures and caused a decrease in the temperature difference between the inlet and outlet temperatures. By decreasing of the outlet air temperature the speed of the outlet air and consequently the rate of air mass flow was reduced and as a result the efficiency was decreased.

\section{References}

Aydin, K. (2005). Effect of heat absorbing media on thermal performance of air-type solar collectors. A thesis submitted to master of science in mechanical engineering, The graduate school of engineering and sciences, Izmir institute of technology.

Bagheri, H., Arab-Hoseini, A., \& Kiyan-Mehr, M. H. (2010). Designing, construction and analysis of lab model solar dryer. Article collection from the sixth national engineering conference on agriculture machinery and mechanization, agriculture and natural resources of paradise, University of Tehran.

Choundhury, C., Anderson, S. L., \& Rekstand, J. (1988). A solar air heater for low temperature application. Journal of Solar Energy, 40(4), 335-343. http://dx.doi.org/10.1016/0038-092X(88)90006-0

Diyani, M. (2002). Control engineering, third edition, Nath cultural-scientific institute.

Fuller, R. J., \& Charters, W. W. S. (1997). Performance of a solar tunnel dryer with microcomputer control. Journal of Solar Energy, 59(4-6), 151-154. http://dx.doi.org/10.1016/S0038-092X(96)00143-0

Garg, H. P., Ranjana, J., Choundhury, C., \& Datta, G. (1991). Theoretical analysis on a new finned type solar air heater. Energy, 16(10), 1231-1238. http://dx.doi.org/10.1016/0360-5442(91)90152-C

Henden, L., Rekstad, J., \& Meir, M. (2002). Thermal performance of combined solar systems with different collector efficiencies. Journal of Solar Energy, 72(4), 299-305. http://dx.doi.org/10.1016/S0038-092X(01)00079-2

Karim, M. A., \& Hawlader, M. N. A. (2004). Development of solar air collectors for drying applications. Energy Conversion and Management, 45(3), 329-344. http://dx.doi.org/10.1016/S0196-8904(03)00158-4

Kurtbash, I., \& Durmush, A. (2004). Efficiency and exergy analysis of a new solar air heater. Renewable Energy, 29(9), 1489-1501. http://dx.doi.org/10.1016/j.renene.2004.01.006

Malekzadeh, Gh., \& Kashanihesar, M. H. (2004). Fundamental of thermodynamic (translation). Nima Publications.

Mokhtari, F., \& Semmar, D. (1999). Etude experimental d'un capteur solaire a air. Rev. Energ. Ren, 243-246.

Nadi, F. (2006). Designing, construction and analysis of active indirect solar dryer for grapes. MS thesis in mechanical engineering of agricultural machinery, faculty of agriculture, university of Tarbiat-e-modaress.

Nybrant, T. G., \& Regner, P. J. S. (1985). Adaptive control for continuous grain dryers. American Society of Agricultural Engineers (USA), Fiche no. 85-3011. ARN: US8636517.

Parker, B. F., Lindley, M. R., Colliver, D. G., \& Murpht, W. E. (1993). Thermal performance of three solar air heaters. Journal of Solar Energy, 51(6), 467-479. http://dx.doi.org/10.1016/0038-092X(93)90132-8

Soheili-Mehdi-zadeh, A. (2009). Designing solar dryer with forced convection for leafy vegetables. MS thesis in mechanical engineering of agricultural machinery, agriculture and natural resources of paradise, University of Tehran.

Soheili-Mehdi-zadeh, A., Mousavi, F., \& Ebrahimi E. (2010). Designing and construction flat and sailed solar collector with specific absorber plate and outlet air control, designed for solar dryer forced convection, Article collection from the sixth national engineering conference on agriculture machinery and mechanization, agriculture and natural resources paradise, University of Tehran.

Zomorodian, A. A., \& Woods, J. L. (2003). Modeling and testing a new once through air solar energy collector. Journal of Agriculture Science and Technology, 5(1-2), 11-19. 
Table 1. The average value of the data in the testing days. Average wind speed $5.3 \mathrm{~m} / \mathrm{s}$ and average relative air humidity $41.7 \%$

\begin{tabular}{ccccccc}
\hline Local time & $\begin{array}{c}\text { The average } \\
\text { inlet air } \\
\text { temperature to } \\
\text { the collector } \\
\left({ }^{\circ} \mathrm{C}\right)\end{array}$ & $\begin{array}{c}\text { The average } \\
\text { outlet air } \\
\text { temperature } \\
\text { from the } \\
\text { collector }\left({ }^{\circ} \mathrm{C}\right)\end{array}$ & $\begin{array}{c}\text { The average } \\
\text { speed of the fan } \\
(\mathrm{rpm})\end{array}$ & $\begin{array}{c}\text { The average } \\
\text { speed of outlet } \\
\text { air from the } \\
\text { collector }(\mathrm{m} / \mathrm{s})\end{array}$ & $\begin{array}{c}\text { The average of } \\
\text { radiation value } \\
\text { in A state } \\
\left(\mathrm{W} / \mathrm{m}^{2}\right)\end{array}$ & $\begin{array}{c}\text { The average of } \\
\text { radiation value } \\
\text { in B state } \\
\left(\mathrm{W} / \mathrm{m}^{2}\right)\end{array}$ \\
\hline $8-9$ & 21.6 & 38.2 & 487.7 & 0.42 & 1080.2 & 949.5 \\
$9-10$ & 24 & 39.4 & 592.4 & 0.51 & 1108.1 & 1032.9 \\
$10-11$ & 27.4 & 40.6 & 785.9 & 0.67 & 1208.4 & 1108.9 \\
$11-12$ & 30.6 & 43.7 & 1006.9 & 0.86 & 1242 & 1184.4 \\
$12-13$ & 32.6 & 44.6 & 1081.3 & 0.91 & 1264.9 & 1200.8 \\
$13-14$ & 33.7 & 45.9 & 1223.3 & 1.1 & 1248.9 & 1147.8 \\
$14-15$ & 33.1 & 44.8 & 1108.6 & 0.97 & 1209.3 & 1097.2 \\
$15-16$ & 30.6 & 43.6 & 961.4 & 0.84 & 1119.4 & 1017.3 \\
$16-17$ & 28.9 & 42.9 & 914 & 0.8 & 998.5 & 918.4 \\
$17-18$ & 26.7 & 41.5 & 787 & 0.69 & 877.5 & 768.1 \\
$18-19$ & 23.7 & 40.7 & 690 & 0.6 & 714.1 & 830.4 \\
$19-20$ & 22.3 & 39.3 & 594.4 & 0.53 & 672.1
\end{tabular}

A: In this state, the solar meter is positioned vertically to the sun's rays and tracking sun about 15 degrees in every hour.

B: In this state the collector is positioned in 29.5 degrees and is exposed to sun's rays in a fixed position and the solar meter in parallel with the collector measures sun's radiations.

Table 2. The average values of calculation and measuring parameters in the testing days. The area of the surface of the collector $=2 \mathrm{~m}^{2}$

\begin{tabular}{|c|c|c|c|c|c|c|c|}
\hline local time & $\begin{array}{c}m \\
(\mathrm{~kg} / \mathrm{s})\end{array}$ & $\begin{array}{c}C_{p} \\
(\mathrm{~J} / \mathrm{kg} \circ \mathrm{K})\end{array}$ & $\begin{array}{l}\Delta T \\
(\circ \mathrm{K})\end{array}$ & $\begin{array}{c}I_{\beta} \\
\left(\mathrm{W} / \mathrm{m}^{2}\right)\end{array}$ & $\begin{array}{l}Q_{\text {useful }} \\
\text { (W) }\end{array}$ & $\begin{array}{c}Q \\
(\mathrm{~W})\end{array}$ & $\begin{array}{c}y_{\text {Collector }} \\
(\%)\end{array}$ \\
\hline $8-9$ & 0.015 & 1003 & 16.6 & 949.5 & 249.7 & 1899 & 13.1 \\
\hline $9-10$ & 0.018 & 1003 & 15.4 & 1032.9 & 278 & 2065.8 & 13.5 \\
\hline $10-11$ & 0.024 & 1003 & 13.2 & 1108.9 & 317.8 & 2217.8 & 14.3 \\
\hline $11-12$ & 0.031 & 1003 & 13.1 & 1184.4 & 407.3 & 2368.8 & 17.1 \\
\hline $12-13$ & 0.033 & 1003 & 12 & 1200.8 & 397.2 & 2401.6 & 16.5 \\
\hline $13-14$ & 0.04 & 1003 & 12.2 & 1147.8 & 489.5 & 2295.6 & 21.3 \\
\hline $14-15$ & 0.035 & 1003 & 11.7 & 1097.2 & 410.7 & 2194.4 & 18.7 \\
\hline $15-16$ & 0.03 & 1003 & 13 & 1017.3 & 391.2 & 2034.6 & 19.2 \\
\hline $16-17$ & 0.029 & 1003 & 14 & 918.4 & 407.2 & 1836.8 & 22.2 \\
\hline $17-18$ & 0.025 & 1003 & 14.8 & 830.4 & 371.1 & 1660.8 & 22.3 \\
\hline $18-19$ & 0.022 & 1003 & 17 & 672.1 & 375.1 & 1344.2 & 27.9 \\
\hline $19-20$ & 0.019 & 1003 & 17 & 589.5 & 323.9 & 1179 & 27.5 \\
\hline
\end{tabular}

The values of $C_{p}$ is extracted from the thermodynamic tables (Malekzadeh and Kashanihesar, 2004). 


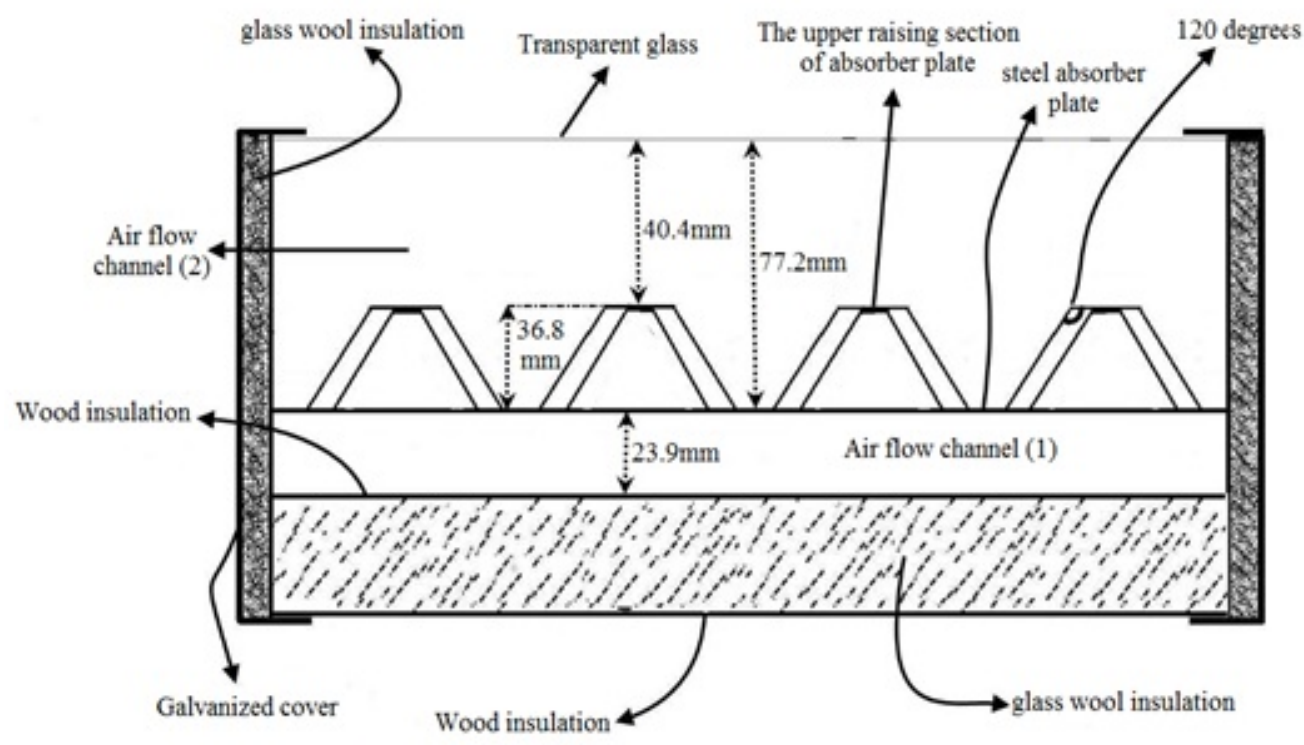

Figure 1. Schematic cross section of collector

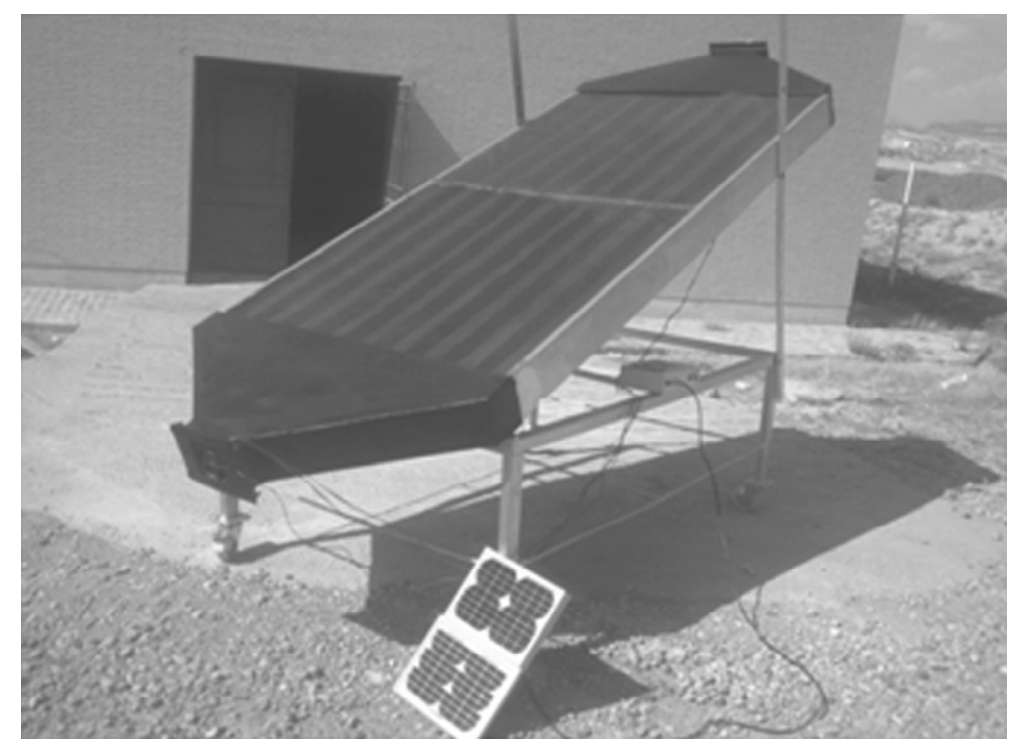

Figure 2. Solar collector equipped with a speed control for the fan with PV feeding source 


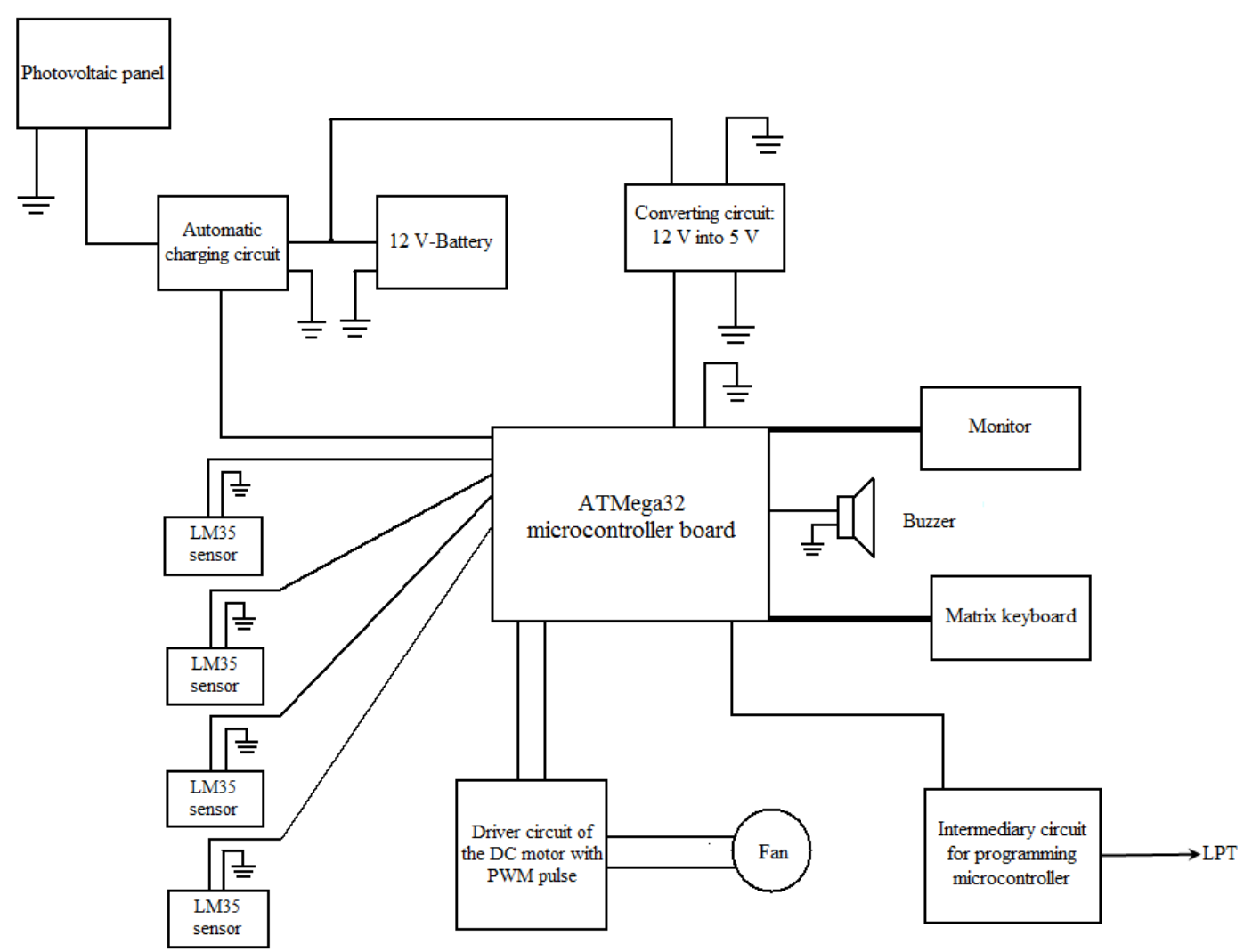

Figure 3. Schematic system for the speed of the fan

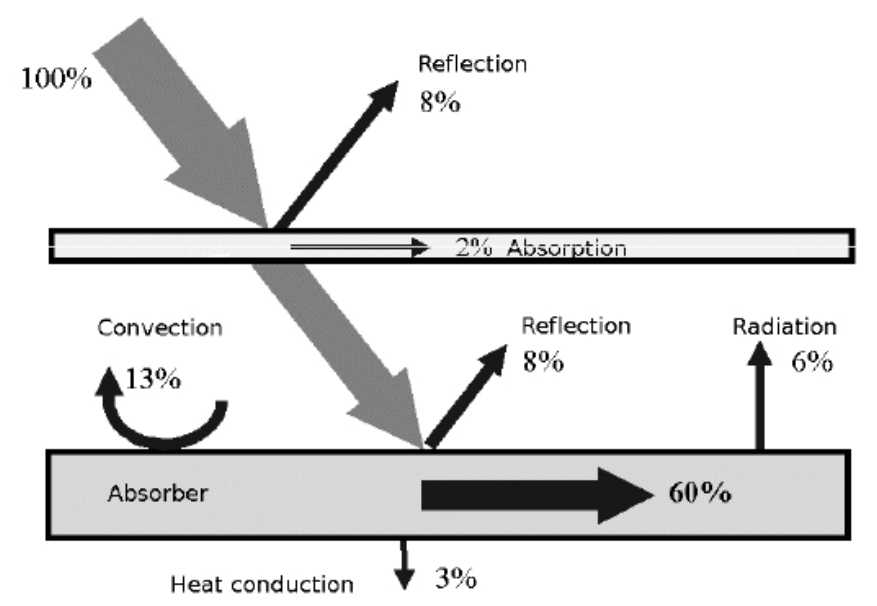

Figure 4. Schematic solar radiation and different kinds of heat losses in a flat air solar collector 


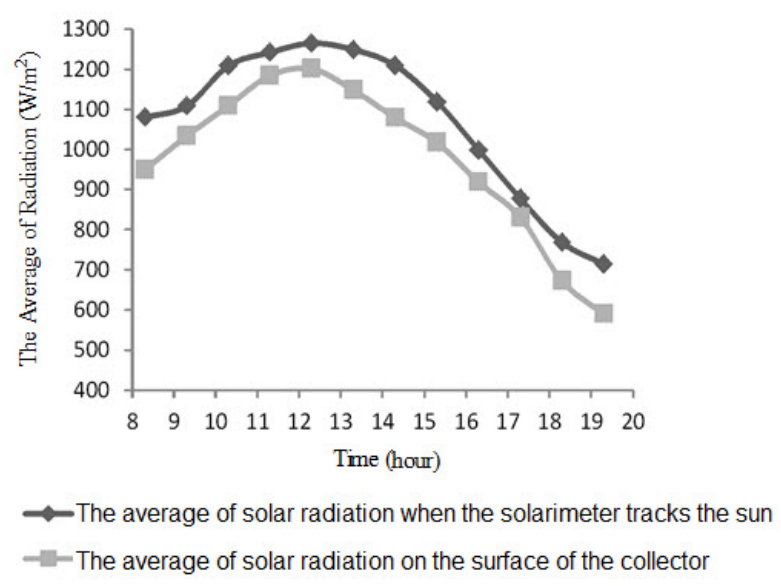

Figure 5. The average of sun radiation in the testing days

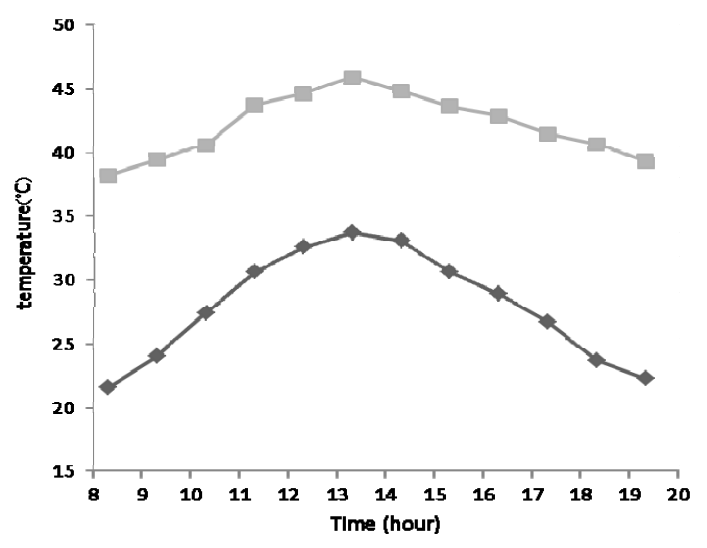

—The average inlet air temperature to the collector

- The average outlet air temperature from the collector

Figure 6. The average of variation of inlet and outlet temperatures as a function of time in the testing days

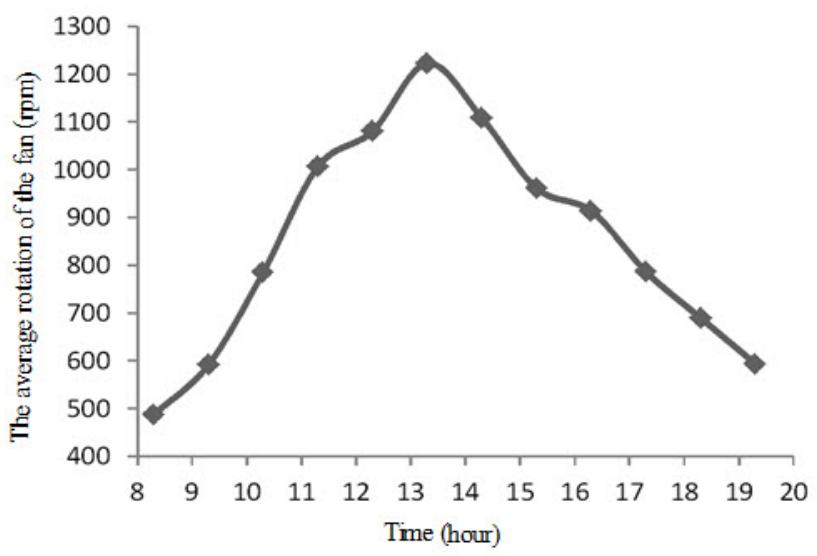

Figure 7. The average of changes in the fan's rotation as a function of time in the testing days 


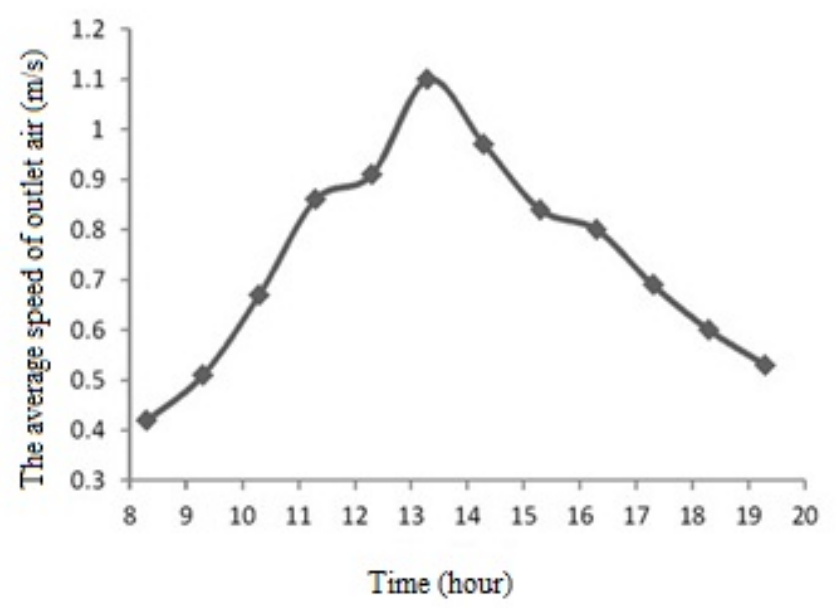

Figure 8. The average of changes in the speed of outlet air as a function of time in the testing days

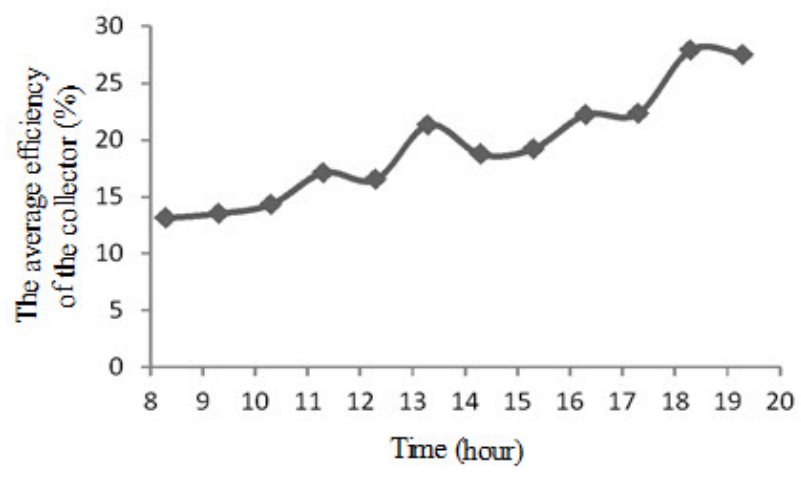

Figure 9.The average efficiency of the collector in the testing days (In the programmed ranges of temperature for microcontroller) 